\title{
40 years within two epochs of two millennia
}

\author{
V. A. Kordium \\ Institute of Molecular Biology and Genetics, NAS of Ukraine \\ 150, Akademika Zabolotnogo Str., Ukraine, 03680 \\ kordium@imbg.org.ua
}

\begin{abstract}
The article-generalization deals with the main directions being developed in the Department of Cell Regulatory Mechanisms during past 40 years from the moment of the Institute of Molecular Biology and Genetics of Academy of Sciences of Ukraine organization up to our days. The main steps of space and molecular biology in the USSR and future development of biology in Ukraine are presented in this review.

Keywords: space biology, molecular biology, gene therapy, transgenic plants, biothechnology.
\end{abstract}

We live in the world of relativity. The world with no absolute, where extremes meet, and the notions of «what is good» and «what is bad» are interchanged ever so frequently, acquiring opposite meanings. The time period of 40 years is also relative in our world. 40 years may be a quiet period with hardly anything to recollect. Or it may be turbulent, complicated, inconsistent, and unpredictable. The last 40 years - the lifetime of our Institute, from the moment of its uneasy launch till this, rather relative, anniversary - happened to be within the period that is hard even to define. These were 40 years when the Institute in general and our department as its constituent witnessed the coming of new millenium, two radically opposite, socio-political systems and several concepts, or, rather, paradigms in science. There was almost complete alteration of generations of scientists, departments, trends, and many other things. We have been the only department, surviving with no changes throughout this long time.

How it all started is a topic of a separate analysis. Still, the specificity of our Institute was its being «composed» pursuant to the State decree from a number of existing departments of different institutes. Our department «entered» this newly organized Institution from the Institute of Microbiology and Virology of the Academy

(c) Institute of Molecular Biology and Genetics, NAS of Ukraine, 2013 of Sciences of the Ukrainian SSR. The subject-matter of the department was rather ambiguous. The evident basis was extraterrestrial biology, while promising results were obtained in the field of molecular biology (at the level of possibilities of that time).

The time of preparation to the establishment of the future Institute and the first stages of its formation coincided with the (worldwide) start of extraterrestrial biology. The latter had not existed until the first flights of satellites (if not consider quasi-scientific fictions, Tsiolkovsky's dreams, and popular scientific articles about some indefinite, though definitely wonderful, future). Extraterrestrial biology was created «from scratch». The absence of technical possibilities, i. e. artificial satellites of the Earth, at those times had ruled out its possible precedence. So, several young people got armed with remarkable age-related adventurism and decided to Start. The principal initiators of the Start were the employees of Korolev's company - a gigantic organizing-engineering-coordinating structure in Podlipki. The author joined this «working group» at their invitation. We were provided with the «board» (with the tightest possible limits of weights and sizes) and financing. All the restany fancies, ideas, design-engineering, methodological and scientific solutions - was solely ours. While the Institute was being created, this work was already in progress. And Kyiv was actually the main scientific center 
of this work. The initial fundamental basics of extraterrestrial biology were created by us: the study on the impact of a cosmic flight on developing organisms (which are not at rest, contrary to what other scientists set as their foundation); the correlation between the time of flight and the time of individual development; the ideology, technical decisions and implementation of experiments, singling out the conditions of a cosmic flight «in pure form», the first devices of universal and multi-purpose use for the study on biological objects during an actual cosmic flight (applied by all the Soviet specialists in their experiments aboard); the principles of conducting these experiments and their application, etc. Sometimes as few as several months passed from the idea to setting an actual experiment aboard. We took decisions (and guaranteed) that we would respect these deadlines, often not even having a scratch. It was based on the principles of our work. We were absolutely sure that every problem could be solved. It was just the matter of finding this solution and implementing it. We did find these solutions, we did implement them. That is how we discovered how to «balance» the ground control with the experiment aboard despite seemingly unsolvable problem - the sedimentation on the Earth and its absence in zero gravity for microorganisms, growing in the nutrient medium. As a result we obtained a strong evidence of the impact of the Flight itself. It was experimentally proven that besides the obvious vector impact on all the living things, the gravity also has a non-vector effect, which does not depend on the size of the object and its location in space. We discovered the conditions to provide plants with «moisture regime» in zero gravity, where water floats in the air and spreads over the surface without «weight-related» limits - and the first plant, ever blossoming in space, was in our experiment. The department formulated the main principle of estimating, planning and forecasting the state of organisms aboard spacecrafts. Its essence was to strengthen the tendency, set forth while conducting the experiment on the Earth. If the created conditions were optimal, the growth (and other indices) in zero gravity (now commonly called microgravity) was enhanced and more intense than on the Earth. If the initial conditions were not optimal, unfavorable - the growth aboard declined. All this did not just happen «in general», but in comparison with the adequate control on the Earth. It was demonstrated that in complex multicomponent biological systems the relations between the components changed, and microorganisms become aggressive towards higher eukaryotes. Actually that was the time of establishing the principal specificities and regularities of the organism's existence in conditions of a cosmic flight [1-6]. At that period American researchers in the field of extraterrestrial biology were far behind us. However, gradually the Space race between the USSR and the USA faded away. The priority military significance was attributed to other questions. Technically, neither developing of new planets (starting with the Moon), nor creation of technological extraterrestrial production at current technical possibilities was possible; the expenses were ever increasing and became unmanageable, and the economic and military sense was vague and indefinite. The Lunar rockets Saturn S5, produced in the USA, were not used for lunar programmes, save those for prestigious astronauts' flights. In the USSR, after one successful flight, the multi-use Buran space shuttle was dismissed and destroyed with time. The Soyuz, Mir, and Salyut space stations used up all their resources, entered dense atmosphere and ceased to exist, etc. The department was gradually winding down its work in the field of extraterrestrial biology and moving to molecular biology. This work started with our research on biological effects of exogenous RNA. The results of the effects - growth stimulation, phenotype change - were extremely unstable and even paradoxical in some cases [7-9]. These were the first foregoers of RNA technologies. However, their time was yet to come. Since stable reproducible results were not achieved, the work in this area was terminated. It was more interesting to study the possibility of transforming plants using DNA. In collaboration with V. V. Morgun we obtained the transformation effect in corn [10]. The efficiency was not high. This work took too much time even the minimal cycle of one research lasted a year (a plant had to pass the whole vegetation cycle, and the genetic analysis required the second generation). There was no precision in transferring required and economically valuable properties during «total transformation». The transformation via processing of the recipient by the genetic material, isolated from the donor, was not developed. However, at that time the world already had the first perfect systems of plant transformation on the basis of Ti plasmid of Agrobacterium tumefaciens - the 
world entered the era of transgenic plants $[11,12]$. We set up the same system [14].

However, it was the time of Epoch change - the time when a great super-state, the USSR, passed away. Its place was taken by certain «post-Soviet space» where some new states were formed. The state of Ukraine emerged. The time of the country's formation and the first years of its development are always inevitably critical in either aspect - economically, politically, socially, psychologically, etc. The beginning is always hard and complicated. As for transgenic plants, it was also the time of protests, fears and prohibitions toward them throughout the world. The technologies of obtaining transgenic plants were soon closed by multi-level patent rights. There was no chance to do something actual because of the absence of both conditions to conduct any work and the criterion of being relevant. Still we did work in the field of gene technologies by a wide margin. One of them did find its niche to the full extent. The 1980's witnessed the establishment of industrial implementation of gene technologies. There were the first genetically modified animals and plants. There was the launch of production of «recombinant proteins» - first of all, the human products required for medicine, as well as the products of other organisms for food and chemical industries. At that time the optimal technological solutions were not evident yet, and the potential of plasmid (target gene, located on plasmid) and phage (target gene, located on bacteriophage) technologies was worked upon and discussed for some time. This contest was won by plasmid technologies, as nobody in the world managed to elaborate practically convenient, simple and low-cost phage technologies. However, we managed to create such a technology: phage-dependent biosynthesis of proteins and peptides [16-20]. We elaborated, checked and introduced it into production. This is the technology of producing human interferon $\alpha 2 \beta$ in Ukraine [21]. We formulated the idea of gene therapy of mass pathologies [22, 23]. Surely, now universal nature of gene therapy is obvious. Yet in the beginning it was limited only to hereditary monogenic diseases and was named human gene engineering. We triggered the idea and experimental work on gene therapy of insulin-dependent diabetes and atherosclerosis [24-29]. The change of Epochs, Systems and financial tsunami because of them blocked this work for a long time. Now it is de- veloping, and the work related to diabetes is close to its technological completion.

All along we have been developing our own, unique vision of the living beings. The first stage in the formation of this vision was an analysis of evolution and status of the Biosphere. In 1982 the Evolution and Biosphere monograph was published [30], which considered the evolution from the point of view of horizontal transfer of genetic information within the integrated and interconvertible informational system - the Biosphere. These ideas were developed and generalized as time went on. At the moment of monograph publication, similar ideas were accepted to a limited degree, and only for prokaryotes, so the author was criticized immensely and harshly. Gradually these ideas were experimentally proven and today they are actually acknowledged worldwide. The next stage in the development of the new vision was the formation of ideas about the organism as a special unified internally-closed informational system. The system, where all organism cells are united not only by trophic and signaling connections but also by the common interconvertible system. At first it was the subject of several publications [31-33]. These were followed by a generalizing monograph - «Our «Shagreen leather» is our problem. We have to solve it ourselves» [34]. Later these ideas were experimentally developed and theoreti- cally improved [35-37].

It is obvious that these ideas cannot be commonly accepted on the spot. The biosphere is a common informational system. Therefore, for the wholeness of conceptions about it, we formulated new notions, related to the microworld - microcenoses [38-41]. At present there are enough scientific data and experimental proofs to confirm them.

Everything in the world develops not «according to the plan», but in the way, inconceivable for us - simultaneously, along the whole field of human civilization, «all of a sudden» and irregularly. The biotechnology gradually changed in a similar way. Having started millennia ago with production of sour milk, baking bread with yeasts, and wine-making, it had the first high rise one hundred years ago, with the development of fermentation industry and the launch of «microbiological industry». Then there was rapid extension of the industry and increased interest to it due to Fleming's discovery of penicillin. Finally, the next world-leading stage ca- 
me - the combination of gene technologies as universal creation and production of «recombinant» products and transgenic organisms.

At the beginning of new millenium there was extremely rapid development of cell technologies. Nowadays we witness vigorous incorporation of cell and gene technologies. A Human Being is a target of these research and application. Still in a vague form, but clearly objective, the task is set - complete technological arrangement of a human being. This is why the fundamental science is applied in full measure and a principally new area is being formed - Fundamental Biotechnology. The task of the fundamental science is to study. To study! To study everything a human can possibly reach. The task of the fundamental biotechnology is to control all the li- ving beings in the full scale. To control and govern! A human being, first and foremost. For the time being, it is absolutely humanistic approach: to protect, to cure, to restore, but in the foreseeable future - to transform, to modify, to reproduce, and all the rest to be possibly thought of. By historical standards, the development of this trend is explosive. To date there observed an integration of some sections of biotechnology for the purpose of completing this task. One of these unions is the interpenetration of gene, cell and signaling technologies. There are no separate parts in the organism, everything interacts, inter-coordinates, interchanges, etc. In this area, the department was elaborating the cytokine therapy (restoration of blood supply of the ischemic kidney) [42-43], gene therapy (simulations of diabetes and atherosclerosis) [22-29], cell therapy (on the basis of the protocol of obtaining mesenchymal multipotent cells from gelatin of Wharton) [44]. As for the precise technological support (purification, testing, delivery, etc.), we set up and are developing the technology of recombinant single-strand monoclonal antibodies [45-47]. Now we started uniting all these to obtain the «inter...»effects - the elaboration of technologies of applying genetically modified cells on the background of cytokine field in the damaged part of the organism to reconstruct the desired using stem cells of the same organism. At the beginning, the laboratory animals were used. Still, a new level has already been launched, as these studies are organized in cooperation with medical institutions. World science and technologies set «large-scale» tasks and solve everything to the fullest extent. Fundamental biology has already «disassembled» a human being into all his constituents - organs, tissues, macromolecules, metabolism pathways, signaling chains and cascades, hereditary apparatus, and all the rest. This «disassembly» is as deep as the quantum level, and this process will go deeper and wider. Meanwhile, fundamental biotechnology starts assembling the human being out of all his constituents. As of now, the level is rather limited: introduction of new genes into the existing genome; gene replacement; synthesis of minigenomes starting with the mycoplasmal one; substitution of damaged cells with new ones; introduction of genetically modified cells to restore tissue structures and organ functions; changing the effect of signaling pathways via target cytokine-receptor transformation, etc. All these are being developed with such a rate that the process is flash-like not only by historical standards, but also on the scale of the human life. This is the field, where a new stage of department work is getting its beginning. Working in it, we are simultaneously the creators, implementers and objects. That is our perspective.

\section{B. А. Кордюм \\ 40 років у двох епохах двох тисячоліть}

Резюме

В огляді описано основні наукові напрямки, які розроблено у відділі регуляторних механізмів клітини за минулі 40 років - з моменму організаиії Інституту молекулярної біології і генетики НАН Украӥни. Представлено також головні етапи становлення космічної і молекулярної біології в СРСР та подальший розвиток біологічної науки в Украӥні.

Ключові слова: космічна біологія, молекулярна біологія, генна терапія, трансгенні рослини, біотехнология.

\section{B. А. Кордюм}

40 лет в двух эпохах двух тысячелетий

Резюме

В приведенном озоре описаны основные научные направления, разрабатываемые в отделе регуляторных механизмов клетки за прошедшие 40 лет - с момента организации Института молекулярной биологии и генетики НАН Украины. Представлены также главные этапь становления космической и молекулярной биологии в СССР и дальнейтее развитие биологической науки в Украине.

Ключевые слова: космическая биология, молекулярная биология, генная терапия, трансгеннье растения, биотехнология.

\section{REFERENCES}

1.Kordium V. A., Polyvoda L. V., Mashinskii A. V. The influence of the conditions of space flight on microorganisms // Gravitation 
and organism. Problems of space biology.-Moscow: Nauka, 1976.-Vol. 33.-P. 238-260.

2. The influence of the conditions of space flight on developing organisms / Ed. V. A. Kordium.-Kyiv: Naukova dumka, 1978.$160 \mathrm{p}$.

3. Kordium V. A., Polyvoda L. V., Man'ko V. G., Babskii V. G., Kon'shin N. I., Polishuk L. P., Moshinskii A. V., Gavrish T. G. The results of the experiment «The growth of microorganisms» in spaceship «Soyuz-22» // Space investigations in Ukraine: Rep. Interdepartmental Com.-Kyiv: Naukova dumka, 1978.-Vol. 12.-P. 3-14.

4. Kordium V. A., Sytnik K. M., Babskii V. G., Man'ko V. G., Neduha E. M., Popova A. F. Microorganisms in the space flight.Kyiv: Naukova dumka, 1983.-156 p.

5. Kordium V. A., Dubinin N. P., Vaulina E. N., Sytnik K. M., Palnbakh L. R., Vinnikov Ya. A., Kostina L. N., Polivoda L. V., Kordyum E. L., Anikeev M. D., Kogan M. G., Jordanishvili E. K., Laurak E. A,. Konshin N. I., Mashinsky A. L. Biological investigation of higer and lower plants at board Seyus 19 // Life Sci. Space Res.-1977.-15.-P. 113-118.

6. Kordium V. A., Kordium E. L., Nefedov Iu. L. The growth and cell structure characteristics of Proteus vulgaris cultivated in conditions of weightlessness in «Cytos» apparatus // Biological studies on orbital stations «Salut».-Moscow: Nauka, 1984.-P. 33-38.

7. Kordium V. A., Kirillova V. S., Likhacheva L. I. Biological action of exogenous ribonucleic acids // Herald of AS of Ukrainian SSR.-1977.-N 6.-P. 67-77.

8. Kordium V. A., Kirillova $V$. S. The expression of exogenous RNAs in eukaryotic and prokaryotic cells // Coll. «Molecular Biology»: Republic Interdisciplinary Coll.-Kyiv: Naukova dumka, 1977.-18.-P. 62-70.

9. Kordium V. A., Kirillova V. S. Phenotypic and genotypic effects of exogenous ribonucleic acids // Coll. «Molecular Biology»: Republic Interdisciplinary Coll.-Kyiv: Naukova dumka, 1978.-19.-P. 28-32.

10. Kordium V. A., Morgun V. V., Chernykh S. I. The transfer of dominant gene sul in corn with the help of exogenous DNA // Dokl. Akad. Nauk USSR.-1974.-N 8.-P. 759-762.

11. Zambryski P., Joos H., Genetello C., Leemans J., Van Montagu $M$., Schell J. Ti plasmid vector for the introduction of DNA into plant cells without alteration of their normal regeneration capacity // EMBO J.-1983.-2, N 12.-P. 2143-2150.

12. Deblaere R., Bytebier B., De Greve H., Deboeck F., Schell J., Van Montagu M., Leemans J. Efficient octopine Ti plasmid-derived vectors for Agrobacterium-mediated gene transfer to plants // Nucl. Acids Res.-1985.-13, N 13.-P. 4777-4788.

13. Dobachevskaya O. N., Rymar S. E., Kordijum V. A. The influence of UV irradiation on the transfer of foreign genes into Ti plasmid of Agrobacterium tumefaciens via intermediate vectors // Biopolym. Cell.-1991.-7, N 2.-P. 22-25.

14. Kordium V. A., Chernykh S. I. Super synthesis of beta-galactosidase in Escherichia coli cells // Mikrobiol. Zh.-1977.-39, N 1.-P. 105-106.

15. Kordium V. A., Chernykh S. I. The supersynthesis of the enzymes by bacteria based on imported information // Coll. «Molecular Biology»: Republic Interdisciplinary Coll.-Kyiv: Naukova dumka, 1978.-19.-P. 60-62.

16. Kordium V. A., Chernykh S. I. The fundamentals of biological supersynthesis on the transferred genetic material // Tsitol. Genet.-1980.-14, N 5.-P. 80-86.

17. Kordyum V. A., Chernykh S. I., Medvedeva I. Y. Isolation of nonlysogenic bacteria from $\lambda$-lysogenized strains using antibiotic-resistant phage // Can. J. Microbiol.-1984.-30, N 1.-P. 74-76.
18. Chernykh S. I. Slavchenko I. Yu., Gorlov Yu. I., Terent'ev A. G., Gavrish T. G., Kordyum V. A. Phagedependent overproduction of $\beta$-galactosidase Escherichia coli and working out Its purification // Biopolym. Cell.-1998.-14, N 2.-P. 127-131.

19. Chernykh S. I., Slavchenko I. Iu. Laferon (human recombinant $\alpha-2 b$ interferon)-obtaining and characterization // Laferon in the treatment of cancer and infectious diseases.-Rivne, 1996.P. 21-23.

20. Kordium V. A. Objectives and problems of gene therapy // Biopolym. Cell.-1989.-5, N 2.-P. 5-16.

21. Kordium V. A. Possibilities of gene therapy for treatment and prevention of mass pathologies // Biopolym. Cell.-1990.-6, N 1.P. 12-31.

22. Lukash L. L., Neborachko V. S., Podol'skaya S. V., Varzanova I. S., Titok T. G., Buzhievskaya I. S., Kordium V. A. The expression of exoge- nous human insulin gene in subcultures and clones of cultured fibroblasts // Dokl. Akad. Nauk USSR.-1989.-N 8.P. 71-77.

23. Titok T. G., Kostetsky I. E., Chaikovskaya T. L., Kochubej T. P., Zharova L. G., Kirilenko S. D., Melnik I. M., Silvanskaya E. M., Buzhievskaya T. I., Kordium V. A. Transfer of human preproinsulin gene into streptozotocin diabetic rats // Biopolym. Cell.-1990.-6, N 2.-P. 76-80.

24. Titok T. G., Kostetsky I. E., Tchaikovskaya T. L., Varzanova I. S., Kochubej T. P., Lukash L. L., Kordium V. A. Transplantation of human preproinsulin gene into the insuline dependent diabetic and normal rats // Biopolym. Cell.-1993.-9, N 1.-P. 39-44.

25. Toporova O. K., Novikova S. N., Lihacheva L. I., Suhorada O. M., Ruban T. A., Kozel J. A., Irodov D. M., Kordium V. A. Non-viral gene delivery of human apoAl into mammalian cells in vitro and in vivo // Biopolym. Cell.-2004.-20, N 1-2.-P. 25-32.

26. Toporova O. K., Kyrylenko S. D., Irodov D. M., Kordium V. A. Plasmid vector for the human preproinsuiin gene delivery into mammalian cells // Biopolym. Cell.-2007.-23, N 2.-P. 100-107.

27. Gilchuk Iu. M., Toporova O. K., Novikova S. M., Kordium V. A.. Influence of human apolipoprotein A-1 transgene injection on level of cholesterol and morphology of tissues of rabbits on cholesterol diet // Biopolym. Cell.-2008.-24, N 1.-P. 78-81.

28. Kordium V. A. Evolution and biosphere.-Kyiv: Naukova dumka, 1982.-264 p.

29. Kordium V. A., Shpilevaya S. P., Ruban T. A., Sukhorada O. M., Andriyenko V. I. Autotransformation of mammalian cells // Biopolym. Cell.-2005.-21, N 2.-P. 140-144.

30. Kordium V. A., Shpylova S. P., Andrienko V. I., Sukhorada O. M., Ruban T. A., Deryabina O. G. Transfer of genetic information in an organism // Cell Biol. Int.-2005.-29, N 1.-P. 95-97.

31. Kordium V. A., Shpilevaya S. P., Ruban T. O., Sukhorada O. M. The concept of genetic material exchange between mammalian cells // Biopolym. Cell.-2005.-21, N 4.-P. 335-345.

32. Kordium V. A. Our «Shagreen leather» is our problem. We have to solve it ourselves.-Kyiv: Naukova dumka, 2006.-264 p.

33. Kordium V. A. Mutations: what are they? // Biopolym. Cell.2007.-23, N 3.-P. 215-243.

34. Kordium V. A., Andrienko V. I., Maslova O. A., Shuvalova N. S., Irodov D. M., Ruban T. A., Sukhorada E. M., Likhacheva L. I., Shpilevaya S. P. Fundamental gap in fundamental biology // Biopolym. Cell.-2011.-27, N 3.-P. 235-245.

35. Kordium V. A., Irodov D. M., Maslova O. O., Ruban T. A., Sukhorada E. M., Andrienko V. I., Shuvalova N. S., Likhachova L. I., Shpilova S. P. Fundamental biology reached a plateau development of ideas // Biopolym. Cell.-2011.-27, N 6.P. 480-498.

36. Kordium V. A., Moshynets E. V., Tsapenko M. V., AdamchukChalaya N. I., Irodov D. M., Andrienko V. I., Shpilevaya S. P. 
Microcosm of living: evidence of nonobviousness // Biopolym. Cell.-2008.-24, N 5.-P. 412-425.

37. Kordium V. A., Shpilevaya S. P., Moshynets E. V., AdamchukChalaya N. I., Irodov D. M., Andrienko V. I. Biopolymers and cells in dimension of microbial community architecture. 1. Fenomenology // Biopolym. Cell.-2009.-25, N 2.-P. 150-166.

38. Kordium V. A., Moshynets E. $V$. Biopolymers and cells on the level of microbial architecture. 2. Parallel life, parallel but not life, nonparallel and not life, but what? What is life? // Biopolym. Cell.-2009.-25, N 5.-P. 403-423.

39. Kordium V. A. Biopolymers and cells in dimension of microbial community architecture. 3. Microcenosis, cell, biopolymers what they are? // Biopolym. Cell.-2010.-26, N 4.-P. 327-347.

40. Vozianov O. F., Romanenko A. M., Pirogov V. O., Zubko V. I., Bazalytska S. V., Nikulina G. G., Nikitaiev S. V., Bilogolovska V. V., Guts R. V., Pokholenko Ia. O., Dubey I. Ya., Kordium V. A. Novel systems for the restoration of blood flow in ischemic kidney $/ / 9^{\text {th }}$ Int. Symp. on Frontiers in biomedical polymers (FBPS 2011).-Madeira, 2011.-P. 103-104.

41. Vozianov O. F., Nikulina G. G., Kordium V. A., Pirogov V. O., Serbina I. E. The use of fibroblast growth factor for the correction of lipoperoxidation and energy transfer in kidney under different hypoxia modes // Pharmacology and Pharmaceutical Toxicology.-2011.-N 5 (24).-P. 54-55.

42. Maslova O. A., Kordium V. A., Deryabina O. G. Umbilical cord matrix cells. promising instrument for regenerative medicine // Biomaterials for Stem Cell Therapy: State of the Art and Vision for the Future / Eds L. De Bartolo, A. Bader.-New York: CRC Press, 2013.-P. 212-227.

43. Okunev O. V., Gil'chuk P. V., Irodov D. M., Deriabina E. G. Production and characterization of the single chain antibodies against human alpha2b-interferon // Ukr. Biokhim. Zh.-2005.-77, N 5.P. 106-115.

44. Gilchuk P. V., Okunev O. V., Irodov D. M., Pavlova M. V., Yakovenko $O$. $Y a$. Immobilized single chain antibodies for affinity purification of recombinant human IFN- $\alpha 2 b$ // Biopolym. Cell.2006.-22, N 2.-P. 157-161.

45. Pavlova M. V., Hil'chuk P. V., Pokholenko Ia. O., Nikolaiev Iu. S., Kordium V. A. Construction and characterization of immune combinatorial cDNA library of mouse variable immunoglobuline genes // Tsitol Genet.-2008.-42, N 2.-P. 10-15.

Received 03.04.13 